\title{
Tectonic evolution and intra-cratonic alkaline magmatism within the central Kaapvaal Craton during the Mesoproterozoic
}

Friese, A.E.W.

Geophysical Services Department, Anglo American Corporation, PO Box 61587, Marshalltown 2107, Johannesburg, RSA

\section{Introduction}

After the emplacement of the Bushveld Complex between 2.061-2.054 Ga, crustal growth during the successive Ubendian orogeny $(\sim 2.0-1.75 \mathrm{Ga})$ and the deposition of the Soutpansberg and Waterberg formations at $\sim 1.75-1.7 \mathrm{Ga}$, a remarkable hiatus in sedimentation on the Kaapvaal Craton of approximately $1.7 \mathrm{Ga}$ followed, until the deposition of the Karoo sediments between 280 and $190 \mathrm{Ma}$. During this period, the only geological activity so far recorded within the Kaapvaal Craton occurred in the interval $\sim 1.45-1.0 \mathrm{Ga}$, represented by the intrusion of a number of small carbonatite and alkaline complexes, the Premier-National group of kimberlites and the tholeiitic Timbavati and Trompsburg intrusions. While the craton interior appears to have experienced a relatively inactive period, substantial tectono-magmatic and sedimentary processes occurred around its margins during the Kibaran (Grenville) cycle between 1.6 and $1.0 \mathrm{Ga}$.

Based on newly obtained and reinterpreted published structural, geophysical and isotopic data from the core of the Kaapvaal Craton, especially the Witwatersrand Basin, where an abundance of geological data exists, it will be demonstrated, that the temporal association between the Mesoproterozoic alkaline and kimberlitic magmatism on the Kaapvaal Craton and the Kibaran (Namaqualand-Natal) orogeny are not coincidental, and that the magmatism has been triggered by the orogenic activity along the craton margins. Furthermore it will be shown, that the spatial distribution of the alkaline and kimberlitic magmatism is structurally controlled and that the deformational effects of the Kibaran orogeny within the interior of the Kaapvaal Craton are more dramatic and wider distributed than previously recognised.

\section{Proposed geodynamic model}

With regard to alkaline/kimberlitic magmatism within the Kaapvaal Craton during the Mesoproterozoic, Friese et al. (1995) and Friese (in prep.) proposed a geodynamic model for the tectono-magmatic evolution of the central Kaapvaal Craton (Fig. 1). This model envisages initial north/south- and subsequent northwest/southeast-directed plate convergence to have introduced two main tectonomagmatic cycles within the interior of the Kaapvaal Craton, which were triggered by the Kibaran (Grenville)-age orogenic processes along its southern margin.

During the approximate time interval $1.45-1.35 \mathrm{Ga}$, rifting along the southern margin of the craton resulted in the formation of a juvenile oceanic basin (= Tugela Terrane). Contemporaneous extensional reactivation of Archaean terrane boundaries (suture zones) within the craton resulted in the emplacement of alkaline complexes (e.g. Trompsburg, Brandfort, Pienaars River, Spitskop complexes) predominantly along these major structural discontinuities (Fig. 1). Initiation of a southerly directed subduction zone and associated initial orogenic activity along the southern craton margin during the approximate time interval 1.35-1.25 Ga, led to the partial subduction, deformation and high-grade metamorphism $\left(D_{1}+D_{2}, M_{1}\right.$; Johnston et al., 1997) of the Tugela Terrane. The temporally weakly constrained pre-Ntingwe $\left(\mathrm{D}_{4}\right)$ deformation of the Pongola Supergroup along the southern margin of the Kaapvaal Craton (Matthews, 1990), is interpreted to represent this initial phase of the Kibaran orogenic cycle. North/south-oriented far field stresses induced contemporaneously into the lithosphere of the Kaapvaal Craton, caused the development of north/south-trending extensional fracture zones and associated alkaline magmatism (e.g. Venterspost-Gemspost-Bank-Oberholzer dyke swarm, Stukpan complex) along these fracture zones (Fig. 1). Following a period of about $50 \mathrm{Ma}$ of relative magmatic quiescence within the craton, which appears to coincide with magmatism and sedimentation in an oceanic magmatic-arc and back-arc basin setting (= formation of Mzumbe and Margate terranes) along the southern margin of the craton respectively, the main Kibaran orogenic phase within the NamaquaNatal mobile belt $(\sim 1.2-1.0 \mathrm{Ga})$ resulted in the northward accretion and deformation $\left(\mathrm{D}_{1}+\mathrm{D}_{2}\right.$; Thomas et al., 1994) of the Mzumbe and Margate terranes, as well as in the deformation, retrograde metamorphism $\left(D_{3}+D_{4}, M_{2}\right.$; Johnston et al., 1997) and obduction of the Tugela Terrane onto the southern craton margin. This main orogenic event introduced intense northwest-directed, thick-skinned thrust tectonics to the core of the Kaapvaal Craton, the dextral-transtensional reactivation of the lateArchaean Pongola Rift with the formation of the "Pilanesberg Graben System" in the foreland of the northwesterly verging Kibaran fold and thrust belt, as well as the initiation of a second phase of alkaline magmatic activity, closely associated with and confined to the "Pilanesberg Graben System" (Fig. 1). Besides numerous Mesoproterozoic $(\sim 1.25-1.0 \mathrm{Ga})$ carbonatitic-syenitic complexes and dykes (e.g. 
Pilanesberg, Goudini, Tweerivier complexes, Pilanesberg-East Rand dyke system) and a few, so far undated kimberlite pipe occurrences confined to the "Pilanesberg Graben System" (here occurring either aligned along the NW/SE-striking graben faults, or at the intersection of the earlier $(\sim 1.35-1.25 \mathrm{Ga})$ developed N/S-striking extensional fracture zones with the Pilanesberg graben faults), a close spatial, temporal and structural control of kimberlites can also be clearly demonstrated over the occurrence of the Mesoproterozoic ( $\sim 1.2 \mathrm{Ga}$ ) Premier-National Kimberlite Province near Pretoria, which developed during the second tectono-magmatic cycle, at or nearby the intersection of faults of the "Pilanesberg Graben System" with N/S-striking extensional fracture zones, as well as major, deep-seated Archaean lineaments (suture zones), such as the Kwaggasrant and Swavelpoort Lineaments (Fig. 1).

\section{Conclusions}

Based on the above spatial and temporal considerations it can be concluded, that Mesoproterozoic magmatism within the Kaapvaal Craton was not controlled by deep astenospheric plumes impinging on the base of the lithosphere, but rather by craton-wide operating lithospheric processes, which in turn were triggered by the Kibaran (Grenville)-age orogenic activity along the southern craton margin.

The sites of alkaline magmatism was governed by pre-existing and newly formed lines of intra-cratonic weakness, such as Archaean suture zones, the NW-trending $\sim 2.97 \mathrm{Ga}$ old Pongola rift system, as well as Mesoproterozoic $(\sim 1.35-1.25 \mathrm{Ga}) \mathrm{N} / \mathrm{S}$-striking extensional fracture zones. As such it is proposed, that some of these fault and fracture zones are deep-seated, possibly translithospheric structural discontinuities (see also Friese, this volume), which experienced extensional reactivation when far field stresses were induced into the cratonic lithosphere by the Kibaran-age orogenic processes, hence causing stress release and decompressional melting in the upper mantle and allowing the magmatism to penetrate to surface through the continental crust. The proposed geodynamic model for the tectonomagmatic evolution of the central Kaapvaal Craton during the Mesoproterozoic provides important economical implications, e.g. with regard to the erosion and preservation of the auriferous Witwatersrand and Pongola Supergroups, as well as to the identification of areas with a higher incidence of the economically important alkaline magmatism beneath Phanerozoic cover within the interior of the Kaapvaal Craton.

\section{References}

Friese, A.E.W.; Charlesworth, E.G. \& McCarthy, T.S., 1995. Tectonic processes within the Kaapvaal Craton during the Kibaran (Grenville) Orogeny: Structural, geophysical and isotopic constraints from the Witwatersrand Basin and environs. Inform. Circ. Econ. Geol. Res., Univ. Witwatersrand, 292, $67 \mathrm{pp}$.

Friese, A.E.W. (in prep.). The tectono-sedimentary evolution of the southern Free State Goldfield within the Witwatersrand Basin, with implications for the development of the Kaapvaal Craton, South Africa. Ph.D. dissertation (unpubl.), Univ. Witwatersrand, Johannesburg, South Africa.

Friese, A.E.W. (this volume). Structural control on kimberlite genesis and crustal emplacement within South Africa and the Kaapvaal Craton during the Cretaceous. Ext. Abstr., Intern. Kimberlite Conference'98, Cape Town, South Africa.

Johnston, S.T.; McCourt, S \& Mitchell, A.A., 1997. The Tugela terrane: Recent insights. Ext. Abstr., TDOGS Conference, Univ. Witwatersrand, Johannesburg, South Africa.

Matthews, P.E., 1990. A plate tectonic model for the late Archaean Pongola Supergroup in southeastern Africa. In: Sychanthavong, S.P.H., (ed.), 324 pp, Oxford Publ., New Dehli, 41-73.

Thomas, R.J.; Cornell, D.H.; Moore, J.M. \& Jacobs, J., 1994. Crustal evolution of the NamaquaNatal Metamorphic Province, southern Africa. S. Afr. J. Geol. 97/1, 8-14. 

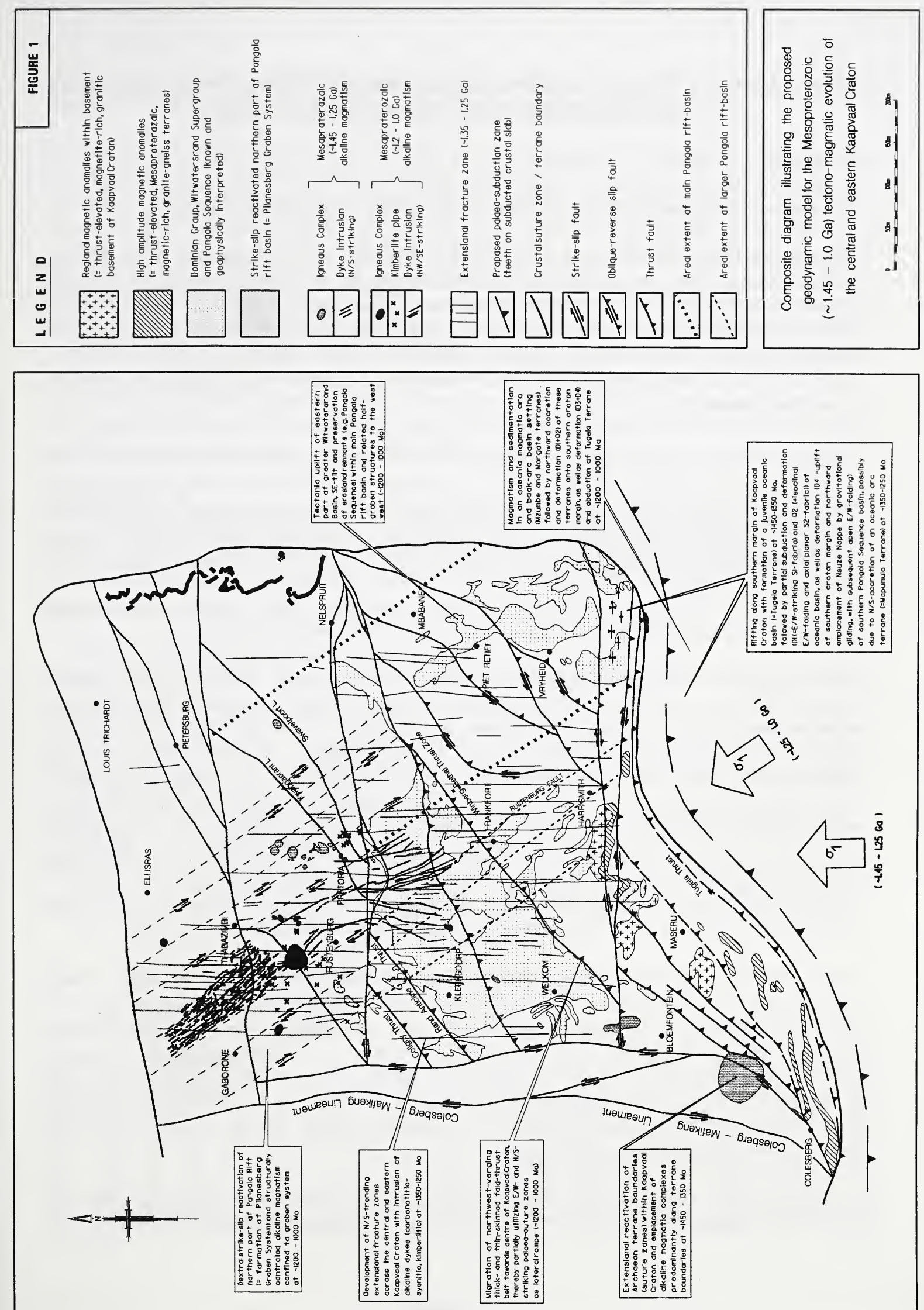